\title{
Dramaturgic Strategy of Glorification on West Sumatera Pageant's Instagram
}

\author{
Alna Hanana ${ }^{1}$, Raka Maulana ${ }^{2}$ \\ \{alna.hanana@gmail.com¹, akulana8@gmail.com² \\ Communication Science Department, Universitas Andalas, Padang, Indonesia
}

\begin{abstract}
In a beauty pageant contest, there is a famous concept of 3B (Brain, Beauty, and Behavior) that need to be fulfilled. In order to satisfy the concept, one of the ways that West Sumatera's pageant did is by using social media especially Instagram. To make a good self-concept as a flawless person of that 3B criteria, West Sumatera pageant organize their Instagram feeds with an impression management strategy called glorification. This research is using constructivism paradigm of qualitative approach and coding analysis. This research aims to look at the strategy that used by West Sumatera's pageant to manage the glorification impression on their Instagram account. This research is using Dramaturgy Theory bg Erving Goffman that focus on the strategy of management impression. The results of this research show that West Sumatera's pageant made a self-concept that made them looks good in front of the Instagram followers by using five strategies such us ingratiation, competence, intimidation, exemplification, and supplication. These strategies were used to expedite the self-image of West Sumatera's pageant in order to look good and to attract another Instagram user's attention.
\end{abstract}

Keywords: West Sumatera's Pageant, Glorification, Dramaturgic, Impression Management Strategy.

\section{Introduction}

The development of communication technology in recent years, especially the internet increasingly rapidly. Technology is now also a part of human life. Aspects of social, economic, cultural, and political aspects have entered a more modern era. The development of this communication technology will cause anxiety about the effects of media on audiences and audience. Shaping the pattern of community life becomes an important role owned by the media. Media becomes the benchmark for people to get information, especially for the information society, they can easily access all the information they need [1]. Its nature can be a benchmark for society; people can easily trust information spread over the internet.

The advantage of social media is the high level of interaction between users who have connections where users can send comments to each other's friends post or directly chat and send messages such as email. Such social media capability is seen by capitalism as an 
opportunity to create needs in society. The high interaction between one users with another user makes each user want to give a good image in the eyes of the public. The society is pushed increasingly competitive in shaping the existence of self [2].

One of the social media that became a container in the formation of self-existence is Instagram. Instagram focuses heavily on its purpose of becoming a mediator of communication through pictures or photographs so that everyone can "communicate" with photos. It is a new form of communication where communication is no longer a verbal form but also in the nonverbal form of the image [3]. Social media such as Instagram to form a visualization of a person with all its activities. Such media can shape and build public opinion using good visualization and community expectations [4]. One of the Instagram users who have to maintain their image and visualization is the pageant actor, which is now a lot of personal page account instances.

The use of social media Instagram become one of the media used Pageant to convey the message in order to form a self-image. The use of Instagram in the world of Pageant is performed both by the Pageant Association and by the instances of each pageant's Instagram. The pageant adds their pageant identity to the bio found on Instagram. The Pageant's Instagram account also personally uploads their activities during a proker, travels to a picnic or photoshoot. Pageant always has three great mottoes called 3B namely, Brain, Behavior, and Beauty [6]. The pageant is present representing an institution or region elected to pageant.

West Sumatra as one of the provinces in Indonesia also holds this Pageant contest such as the Uda-Uni Election, Mr.Tourism, the Maritime Son, the Generation Planning Ambassador, the West Sumatran Manhunt, etc. Once selected, the contestants as Pageants will run several programs depending on the contest or competence they follow - pageant which will represent West Sumatra as well as the regions or institutions that carry the Pageant contest. Automatically the selected Pageant will eventually become a reflection of the area; the institution even becomes the face of West Sumatra. As a representation of the regions and institutions in West Sumatra, the Pageants must describe how good men and women fit the Minangkabau custom philosophy of "Adat Basandi Syarak, Syarak Basandi Kitabullah." This philosophy is based on the definition that custom and religion and related to each other [6]. The concept of $3 \mathrm{~B}$ and the traditional Minangkabau philosophy will illustrate how children should be acting "Minangkabau children should have the nature of their religion and custom." [7]. This young man in Minangkabau should act accordingly, not excessive and in line with religious teachings. Automatically as faces from West Sumatra, Pageant West Sumatra should look at these things in the 3B concept and its role as West Sumatra Pageant.

To fulfill the concept of 3B, West Sumatra Pageant builds self-image against the real life. To prevent the occurrence of meaning bias and the West Sumatra pageant can create a positive image, then the West Sumatra pageant implements the impression management on its Instagram account. To implement the impression management, the pageant figure needs two different stages in its support. The first stage is the front stage where it plays its role, in this case, is the private page of the pageant instant and the second stage is the backstage which is a stage back condition where is no audience knows what the pageant does and is implemented in this case is an activity offline on daily activities. Where this arrangement is carried out with various 
strategies that will eventually support the smooth operation of the impression management arrangement.

\section{Conceptual Framework}

\subsection{Glorification}

Glorification is a self-concept that makes a person look perfect and has no gaps [8]. Glorification can also be defined as self-characterization. Self-characterization or glorification is considered a threat to culture because it is a process of cultural reproduction that aims to sell a thing.

Glorification can also be seen as an exaggerated action of one thing so that the emotions and thoughts of others will be excessively adored and liked [9]. It can be concluded that glorification or self-characterization is an activity that directs others to a self-concept or the desired self-image to look good and get support from something perfect. Because reproduction is a reproduction directed then over time things become the object of glorification will move away from reality.

\subsection{Sumatera Barat Pageant}

Pageant is a contestant or contest that combines the beauty, ingenuity, and behavior of contestants [10]. In the contest, pageant will also be held intelligence tests and personality tests. Thus, the pageant is the person or contestant who follows the contest to find the best person in the field of beauty, ingenuity and contestant behavior.

Pageant has a 3B concept, which is [5]:

1. Brain is a concept that comes into contact with the intelligence of a participant or Pageant.

2. Beauty is a concept associated with the appearance of participants, not necessarily beautiful but good-looking or nice views - not only beauty outside but also beauty inside.

3. Behavior is a point that refers to the beauty factor that is a good personality that can be used as an example.

Pageant West Sumatra is a pageant participant from West Sumatera or represents one of West Sumatera region. To be a Pageant does not have to be chosen as a winner. When entering the contest, especially into the final round, contestants who have followed the event have been referred to as a Pageant. 
As a representative of West Sumatra, it is appropriate that the concept of 3B (Brain, Beauty, Behavior) owned by contestants Pageant rests on Minangkabau adat philosophy namely "Adat Basandi Syarak, Syarak Basandi Kitabullah".

\subsection{Social Media}

Social media is a web-based service that allows users to create profiles, view the list of users available, and invite or accept friends to join the site. The relationship between mobile devices and Internet web pages through "social networks" has become the standard in digital communications [11]. From the explanation can be seen that social media is a virtual space used by users where users can design and use their own and set it according to the will of the user.

Social media management is an act through the editorial table [12]. Everyone has a dream figure who want to be shown on social media. The opportunity to interact and create on social media will be a vast space to present oneself.

Instagram is a photo sharing app that lets users take photos, apply digital filters, and share them with various social networking services, including Instagram's own [13]. Instagram was founded in 2010 by the Burbn Company. Inc. is a company active in mobile application development. Instagram is an application used to provide information in the form of images or video either old or certain period. Instagram itself is one of the most extensive applications with 700 million active users worldwide.

Instagram has interesting and unique features. Like Instagram Story, Filters, Polls, Direct Messages, Bussines Accounts, Love, Story Highlights, etc. The photos on Instagram can be used as memories and can express the current situation and have happened [14].

\subsection{Strategy of Dramaturgy Theory by Jones and Pitman}

The basic assumption of this theory is to emphasize the presence of an actor in playing his role [16]. The self that is displayed in a public space depends on whom the person is interacting with. Dramaturgy is an active and strategic form of improvisation. In the implementation of dramaturgy there are five strategies for constructing the desired self-presentation developed by Jones and Pittman among others [12]:

1. Ingratiation is doing things with the purpose of being liked by others, saying positive things about others and can also be done by saying a few negative things about yourself. In the use of social media, this can be demonstrated by looking at following back activities and giving like other Instagram users.

2. Competence, doing things and activities that make dramaturgy actors are considered to perform and quality. This in social media can be an acknowledgment of ability, 
achievement, performance, and qualifications such as featuring the best work and improving bio on social media.

3. Intimidation, the use of this strategy aims to gain power. Done to appear dangerous. Bringing fear to the opponent, by giving threats, bursting into anger, showing off power or strength. Can be a threat or expression of anger.

4. Exemplification, showing that he is moral and integrity, by showing himself as someone who cares, discipline, honest, generous, and willing to sacrifice. Done to be respected and admired [17].

5. Supplication, self-defeating behavior. It can be seen from the status of impressed mood and the inability to carry out something.

Goffman states that life is like a drama stage [18]. Where there are two sides in the drama's life are front stage and backstage. Goffman describes the effort as impression management, i.e. the steps taken by the actors in building certain impressions in certain situations to achieve specific goals [19].

\section{Methods}

This study used qualitative research methods. Qualitative research constructs social reality, a social reality which is meant by mutual agreement [20]. The relationship between the researcher and the studied and the situation will affect the construction result. This research method is chosen because it is suitably used to see the changes that occur in human life.

The type of research in this research is descriptive research, where this type of research aims to provide an overview by the existing symptoms, it can provide understanding and definition of the symptoms [21]. To be more in-depth, this research focused on the glorification of the West Sumatra Instagram Pageant account by understanding the glorification done by the Pageant of West Sumatra; it will show the management of the impression formed.

Research subjects in this study are the West Sumatran Pageant who has an account Instagram and active use Instagram account. In this study utilize the extracting of primary data and secondary data. Primary data is data obtained from the in-depth interviews of researchers with informants. In this study, primary data were obtained through interviews with Pageant West Sumatra.

Informant selection is done by snowball sampling. This procedure is important to think about who the first informant contacted or meet, because the first informant will give his or her network and acquaintance to the informant, but the researcher has the right to select to whom the researcher will carry out the research. Researcher use Linear Snowball Sampling method. This method allows the researcher to move to find and find new informants and not rely on the first informant even if the first informant gives his informant recommendations [21]. 




Fig. 1. Model of Linear Snowball Sampling

Secondary data is data in the form of documents obtained from the second source. The documents in question can be in the form of previous research, literature, books, photos, websites related to this research.

The collected data should be analyzed to provide clarity of information. Qualitative data in the form of words, sentences or narration obtained from interviews and observation [21]. This research uses coding or coding analysis. The coding in quantitative research is called the labeling or labeling. The etiquette in question is to mark the unit of meaning on any information obtained. Coding is one of the good ways to identify words during interviews or observations.

In this analysis the data are generated from three stages, namely [22]:

1. Open Coding, at this stage the researchers formed the initial category of information that has been obtained before. The information is divided into several segments. This activity is done per sentence which will produce some theme. The details gained from this stage depend on how deep the question will be given.

2. Axial Coding, this stage is also called pivot coding At this stage the researchers classify the themes that have been obtained into several categories. The categories are grouped by similar or similar properties. Axial coding in short combines data from open coding [23]. In this stage the themes are grouped into categories: causal conditions (things that affect phenomena), action strategies / interactions (actions that affect phenomena), and consequences (results or consequences of actions).

3. Selective Coding, identify the story and illustrate the theme of the friend. At this stage the researchers looked at selectively cases or actions that illustrate the previous theme or category so as to simplify research activities.

\section{Impression Management Strategy Pageant West Sumatra}

According to the development of the Goffman dramaturgy concept by Jones and Pittman, there are five strategies and techniques used by actors in personal impression management [12]. In the research findings, these five strategies are also used by pageant of West Sumatra, the strategy include:

1. Ingratiation 
Ingratiation is a technique or personal management strategy that makes a person preferable, in the context of social media, treatment in the form of appreciation like and good commenting can be done [12]. This strategy is also done by pageant of West Sumatra. In the study all informants gave like though some of the informants picked their likes.

Pageant West Sumatera provides like to people they know only. For giving their own comments all informants also claimed to give good comments on some photos that interest him.

\section{Competence}

In the context of social media, competence can be actions that cause a person to be given recognition, acknowledged existence and activities that show achievement. As a pageant of West Sumatra, the title pageant itself has been said to be an achievement.

Not only the title of pageant course, West Sumatra pageant also shows their achievement in theit Instagram account. Besides achievement and degree, competence strategy is also seen from how often the perpetrator doing a job and acknowledged by others. One of the jobs that social media can show is endorsement. Endorsement is authorizing others to support certain products or services under an earlier agreement [24]. Someone who deserves to be the endorser is determined by the manufacturer of the product because only the producer knows what is wanted and who the target of the goods [25]. This indicates an endorser is considered to have competencies that match the goods.

3. Intimidation

Content threats, satire, and annoyance are strategies of intimidation in social media. This strategy is also demonstrated by activities by criticizing others who are impeding their performance or displaying the West Sumatra pageant's disappointment towards others.

The hints, disappointments, and anger performed are shown to show the power it has to have power [12]. The use of intimidation to show power is reserved for others including enemies or opposites from the daily life of the pageant. Enemies here are haters, friends themselves, and others who are thought to be impeding the management of the impression of pageant West Sumatra.

\section{Exemplification}

The West Sumatran Pageant who carries out this strategy shows care, critical content, and high moral standards. In the context of social media can be seen from his concern for an issue, big day and comment on new issues. According to Jones and Pittman, exemplification shows sacrifice, interfacility and can also serve as a selfprotection to cover certain things or self-denial [17]. 
This is indicated by the pageant of West Sumatra to facilitate the management of his impression and show the position that pageant West Sumatra possesses.

\section{Supplication}

Supplication in social media can be shown in the form of status of the mood, pleading for help, fatigue, and so on. This strategy can be seen from the use of captions associated with it. Pageant of West Sumatra states that the use of status of mood, pleading for help, fatigue, etc. is intended to get the attention of others.

\section{Conclusion}

Front and rear stage management by West Sumatera pageant requires strategies that support the success of the front and back stage. Such strategies can include appreciation, intimidation, self-worth, show caring, and show an inability to attract the sympathy of others. The management of the glorification impression is derived from self-image that only shows the good side of the West Sumatra pageant while the bad side is stored inside. Through good attitude will show a good personality, with selection and editing will perfection. Pageant of West Sumatra with perfect person and good manner For futher research we would like to sugest to do a research on a bigger city or bigger competition like Miss Indonesia, or even Miss Universe. It because of their are more popular than pageant in Padang City, and easily persuade person with their post on instagram.

\section{References}

[1] Salamoon, D. K. (2013). Instagram, Ketika Foto Menjadi Mediator Komunikasi Lintas Budaya Di Dunia Maya. Jurnal Airlangga, 1(1).

[2] Douglas, K. (2010). Budaya Media/Identitas/Politik Antara Modern dan Postmodern. Yogyakarta: Jalasutra.

[3] Nasrullah, R. (2004). Teori dan Analisa Media Siber. jakarta: Prenadamedia Group.

[4] Kertamukti, R. (2015). Studi Kualitatif Komunikasi Visual dalam Pembentukan Personal Karakter Account Instagram @ basukibtp. Jurnal Komunikasi PROFETIK, 8(1), 57-66.

[5] Kalnayamitra. (2013). Analisa Media. jakarta: Pusat Komunikasi dan Informasi Perempuan.

[6] Zainuddin, M. (2013). Minangkabau dan Adatnya Adat Bersendi Syarak Syarak Bersendi Kitabullah. Yogyakarta: Ombak.

[7] Ronidin. (2006). Minangkabau di Mata Anak Muda. Padang: Andalas University Press.

[8] Asmara, R. (2016). Strategi Kebahasaan Presiden Jokowi Dalam Menanamkan Ideologi Dan Manifesto Pemerintahan. Litera, 15(2).

[9] Netari, M., Rahayu, L. M., \& Saidi, A. I. (2017). PARODI CALON ARANG DALAM NOVEL JANDA DARI. Pesona, 3(1), 25-42. 
[10] Hermansyah. (2017). Kontes Kecantikan dan Eksploitas Perempuan dalam Media. Jurnal Pustaka BUdaya, 4(1), 26-38.

[11] Briggs, A., \& Burke, P. (2006). Sejarah Sosial Media Dari Gutenberg sampai Internet. Jakarta: Yayasan Obor Indonesia.

[12] Hamidati, A., Ayu, D., \& Melissa, E. (2011). Komunikasi 2.0 Teoritisasi dan Implikasi. Yogyakarta: Mata Padi Pressindo.

[13] Saputro, D. H., \& Dinianti, A. (2017). Manajemen kesan pengguna media sosial instagram dalam mengeksistensikan pancasila. Wacana, 16(1), 57-83.

[14] Instagram. (2017). About Us. Retrieved November 28, 2017, from www.instagram.com/about/us/

[15] Nasiri. (2015). Meneropong pelaku kawin misyar di Surabaya dari sudut dramaturgi. Ijtihad, Jurnal Wacana Hukum Islam Dan Kemanusiaan, 15(2), 199-218. https://doi.org/10.18326/ijtihad.v15i2.199-218

[16] Jones, P. (2010). Pengantar Teori-Teori Sosial. Jakarta: Yayasan Obor Indonesia.

[17] Alim, C. A. (2014). Impression Management Agnes Monica Melalui Akun Instagram (@ agnezmo ). Jurnal E-Komunikasi, 2(3), 1-10.

[18] Silaen, S. F. R. (2015). Dramaturgi Citra Pemimpin Korea Utara Kim Jong Un Dalam Film The Interview Produksi Columbia Pictures. Universitas Sumatera Utara.

[19] Anasari, N., \& Handoyono, P. (2015). Media Sosial Sebagai Panggung Drama ( Studi Deskriptif Presentasi Diri Pengguna Twitter di Kalangan Mahasiswa Unesa ). Paradigma, 3(3), 1-5.

[20] Mulyana, D., \& Solatun. (2013). Metode Penelitian Komunikasi Contoh Contoh Penelitian Kualitatif Dengan Pendekatan Praktis. Bandung: PT Remaja Rosdakarya.

[21] Bungin, B. (2012). Penelitian Kualitatif. Jakarta: Kencana.

[22] Emzir. (2011). Metodologi Penelitian Pendidikan Kuantitatif \& Kualitatif. Jakarta: PT Raja Grafindo Persada.

[23] Wardhono, V. J. W. (2011). Penelitian Grounded Theory, Apakah Itu? Bina Ekonomi Majalah Ilmiah Fakultas Ekonomi Unpar, 15(1), 23-35.

[24] Shrum, L. J. (2010). Psikologi Media Entertainment Membedah Kemampuan Periklanan Subliminal dan Bujukan yang Tak Disadari Konsumen. Yogyakarta: Jalasutra.

[25] Lomboan, S. (2013). The Impact Of Celebrity Endorsment On Brand Image. EMBA, 1(3), 788795. 